\title{
The Role of Histaminergic H2 Receptors on Spasmolytic Activity of Hydroalcoholic Extract of Parsley (Petroselinum crispum) Seeds in Isolated Rat's lleum
}

\author{
Tahereh Heidari ${ }^{1}$, Ahmad Ali Moazedi ${ }^{1}$, Seyyed Mansoor Seyyednejad ${ }^{1}$ and \\ Mehdi Pourmehdi Borojeni ${ }^{2}$ \\ ${ }^{1}$ Department of Biology, Shahid Chamran University, Ahwaz, Iran \\ ${ }^{2}$ Department of Food Hygiene, Faculty of Veterinary Medicine, Shahid chamran, Ahwaz, Iran; \\ tahehehheidari62@yahoo.com
}

\begin{abstract}
Objective: The long traditional history of anti-spasmodic effects of Petroselinum Crispum on the gastrointestinal system, and considering histamine receptors in rats ileum, to elucidate the role of the histamine receptor in function relate intestinal motility in this study investigate the effects of histamine and antagonists $\mathrm{H} 2$ receptor (Cimetidine) on contractions of adult male rat's ileum. Methods: In this study, $2 \mathrm{~cm}$ of terminal isolated adult male rat's ileum in an organ bath containing the oxygenated Tyrode solution $\left(37^{\circ} \mathrm{C}, \mathrm{PH}=7.4\right)$ was used and placed under 1 gram tension contraction induced by $60 \mathrm{mM}$ potassium chloride. The effect of parsley extract was measured in presence of histamine and antagonists $\mathrm{H} 2$ receptor (cimetidine) and their effects on the rat.s ileum contractions were recorded by using Harvard oscillograph. Results: The parsley extract reduced ileum contraction induced by $\mathrm{KCl}$ in a dose-dependent manner $(P<0.001, n=7)$. Spasmolytic effect of extract after tissue exposure to histamine $(0.1 \mathrm{mg} / \mathrm{ml})$ as an agonist and cimetidine $(0.004 \mathrm{mg} / \mathrm{ml})$ did not decrease ileum contractions. Conclusion: Although Parsley seeds extract reduced rat ileum contraction, it seems that $\mathrm{H} 2$ histamine receptors (cimetidine) are not involved in this activity.
\end{abstract}

Keywords: Cimetidin, Contraction, Histamine, Isolated lleum, Rat's

\section{Introduction}

The World Health Organization (WHO) estimates, around $80 \%$ of the world especially developing countries are indigent on complementary and alternative medicines which are prodigiously derived from herbal material ${ }^{1}$.
These days many people start natural product medicine using for intestinal disorders treatment. Natural products have provided as a source of medicines for centuries, and approximately half of the pharmaceuticals use today is developed from natural products ${ }^{2}$.

\footnotetext{
${ }^{*}$ Author for correspondence
} 
Plants are sources of many medicinal drugs. For centuries, herbs have been used in traditional medicine to treat of plenty gastrointestinal disorders ${ }^{3}$. Some herbal teas act as antispasmodics ${ }^{4}$.

Gastrointestinal disorders are the most common problems affecting the general population. Synthetic drugs are present, however, with low efficacy and high side effects ${ }^{5}$. Disorders such as diarrhoea are a major problem in the developing countries. Therefore it was the cause of millions of deaths ${ }^{2}$.

One of the plants that are traditionally used in the treatment of gastrointestinal disorders is Petroselinum crispum, Parsley is a culinary and medicinal herb of the Apiaceae family that grows up to $30-110 \mathrm{~cm}$ high. In folk medicine, different parts of it have been used for different purposes the aerial part of $P$. crispum is used to treat hemorrhoids, the stem for urethral inflammation, and the root is used to pass kidney stones and improve brain function and memory. It also plays the role of carminative stomachic, abortifacient, and nutritive agent. Numerous Studies have shown that $P$. crispum has hypoglycemic, diuretic, hypolipidemic, antimicrobial, and anticoagulant and hepatoprotective properties ${ }^{6}$.

It's also beneficial to cardiovascular and diabetic diseases via anti-inflammatory activities ${ }^{7}$. Characteristic constituents are flavonol glycosides of quercetin, apiol, myristicin and luteolin. phthalides, Terpenes, furanocoumarins apiin, carotenoids, ascorbic acid, and tocopherol are also present in $P$. crispum ${ }^{6}$.

In the previous study, we reported that the inhibitory effect of parsley seed extract on ileum contraction was likely due to the blocking of voltage-gated of calcium channels ${ }^{8}$. Gastrointestinal motility is an integrated process which includes a myoelectric contractile activity, tone, compliance, and transit. Those aspects of motility can be generated and modulated by local and circulating neurohumoral substance ${ }^{9,10}$.

Motor activity of smooth muscles is affected by nerve agents, chemical mediators, drugs and muscle tension. These factors through affecting the cellular mechanisms of muscle activity cause muscle movements. The factors affecting the muscle ion channels, calcium homeostasis, and cytosolic enzymes change the motor activity of the muscles ${ }^{11}$.

The classical signaling pathway through a contraction is evoked by the entrance of $\mathrm{Ca}^{+2}$ smooth muscle, ca2+ calmodulin (Cam) complex formation and, finally, Myosin Light Chain (MLC) phosphorylation to induce smooth muscle contraction $^{12}$.

The membrane of smooth muscles has calcium channels dependent on higher voltage in comparison with skeletal muscles that have sodium channels dependent on much lower voltage; therefore, mainly the current of calcium ions through sodium and calcium slow channels into the fiber is responsible for the production of the contraction activity ${ }^{11}$.

The enteric nervous system is considered to be an independent nervous system that controls and coordinates gastrointestinal motility. Gastrointestinal motility is regulated by numerous mediators, mainly acetylcholine, histamine, 5-hydroxytryptamine, bradykinins, prostaglandins, substance $\mathrm{P}$ and cholecystokinins which achieve their contractile effects through an increase in cytosolic $\mathrm{Ca}^{3}$.

Histamine is one of the aminergic neurotransmitters and plays an important role in the regulation of several (photo) physiological processes $^{13}$. 
The Role of Histaminergic H2 Receptors on Spasmolytic Activity of Hydroalcoholic Extract of Parsley (Petroselinum crispum)

Seeds in Isolated Rat's lleum

Distinct effects are dependent on receptor subtypes and their differential expression. Within the gastrointestinal tract, histamine is present at relatively high concentrations particularly during inflammatory responses ${ }^{14}$. Histamine is released by degranulation in response to different stimulants, such as anaphylatoxins or cross-linking of their high affinity IgE receptors, and has multiple physiological effects such as increasing vascular permeability, causing smooth muscle contraction, and activation of nerves in immediate hypersensitivity reactions. Many of physiological effects of histamine are mediated through four histamine receptors, H1$\mathrm{H} 4$, expressed on multiple cell types ${ }^{15}$. That belongs to the superfamily of G-protein-coupled-receptor $(\mathrm{GPCR})^{16}$.

Previous observations indicate that histamineinduced contraction of intestinal smooth muscle via stimulation of H1-receptors. $\mathrm{H} 1$ receptor induced by histamine provokes excitatory responses, while stimulation of the $\mathrm{H} 2$ receptor provokes inhibitory actions on various smooth muscle tissues ${ }^{17}$. The $\mathrm{H} 1$ receptor is associated with the phospholipase c-catalysed formation of inositol 1,4,5 triphosphate (IP3) and 1,2 Diacylglycerol (DAG). Histamine induces production of inositol phosphates in several tissues (including the brain, airway, intestinal and vascular smooth muscle) via $G_{\text {aq }}$ protein activation. In other tissues, activation of $\mathrm{H} 1$ receptors can also stimulate adenylyl cyclase and formation of cAMP in any case; alternative signaling pathways can be mediated by the histamine $\mathrm{H} 1$ receptor. The recent result indicated that the function of $\mathrm{H} 2$ receptors $\left(\mathrm{H}_{2} \mathrm{R}\right)$ is mediating the increase of intercellular ca2 concentration and/or IP3 levels were observed. Cimetidine (H2 antagonist) was able to block that effect of histamine on the stomach and the heart ${ }^{13}$ and inhibited the contractile response of the ileum to dimaprit ${ }^{18}$. $\mathrm{H} 2 \mathrm{R}$ is coupled both to adenylate cyclase and to phosphoinositide second messenger systems via separate GTP-dependent mechanisms. Receptor binding stimulates activation of Protein

Kinase C (PKC) and p70S6 kinase. Thus, H2Rmediated impacts on cAMP accumulation have been well documented and had been demonstrated in brain slices, gastric mucosa, fat cells, cardiac myocytes, vascular smooth muscle, basophils and neutrophils ${ }^{16}$.

Despite a considerable number of reported studies for parsley extract, the mechanism of its effect on ileum smooth muscle has not yet been investigated. So the present work was undertaken to evaluate the role of $\mathrm{H} 2$ receptors on the spasmolytic effect of parsley seeds extract in rat ileum and to evaluate its clinical benefits in gastrointestinal disorder.

\section{Materials and Method}

\subsection{Plant Extract}

P. crispum Latifilum seeds were collected in (Octobr 2015) form of the Behbahan and identified by Department of Biology Shahid Chamran University, Ahwaz, Iran. To prepare the hydroalcoholiclic extract of P. crispum the sample was washed and air-dried under shade, graded by an electric blender and powder ( $20 \mathrm{~g}$ ) was extracted by the macerated method using $70 \%$ alcohol $(100 \mathrm{ml})$ for $72 \mathrm{~h}$ at room temperature and were shaken several times every day. The mixture was then filtered (Whatman No.1) and the solvent evaporated (yield: $7.72 \mathrm{~g}$ ). The extract powder was stored at $4^{\circ} \mathrm{C}$ until being used $^{8,19}$.

\subsection{Chemicals and Solutions}

Potassium chloride (KCL) was from Mark (Germany) Histamine and Cimetidine from Sigma (USA). kcl was made as a $(60 \mathrm{mM})$ stock solution in tyrode's solution ${ }^{20}$. Histamine $(0.1 \mathrm{mg} / \mathrm{ml})^{21}$ and cimetidine $(0.004 \mathrm{mg} \cdot \mathrm{ml})^{22}$ were made as, stock solution in tyrode's solution and plant extract stock 
solution was $0.1 \mathrm{~g} / \mathrm{L}$ tyrode's. The composition of Tyrode solution (mM) was: $\mathrm{NaCl}$ (136), $\mathrm{KCl}(5)$, $\mathrm{CaCl} 2$ (2), $\mathrm{NaHCO} 3$ (11.9), $\mathrm{NaH} 2 \mathrm{PO} 4$ (0.26), $\mathrm{MgCl} 2(0.98)$ and glucose $(5.6)^{8,19}$. All reagent's were from Mark.

\subsection{Animal and lleum Preparation}

Male Adult Wistar rats $(225 \pm 25) \mathrm{g}$ used and kept at $20-24^{\circ} \mathrm{C}$ and $12 \mathrm{~h} / 12 \mathrm{~h}$ light/dark cycle and free access to food and water. The rats were housed in cages with the mesh bottom to prevent coprophagy and deprived of food for $24 \mathrm{~h}$ before the experiment but had free access to water. Animals were killed by cervical dislocation, and after the laparotomy, strip $(2 \mathrm{~cm})$ of ileum was dissected from $2 \mathrm{~cm}$ above the ileocaecal junction and intraluminal content flushed out with the cooled oxygenated Tyrode solution. The tissue was mounted in an organ bath $(10 \mathrm{ml})$ containing Tyrode solution $\left(37^{\circ} \mathrm{C}, \mathrm{pH} 7.4\right)$ between two stainless steel hooks and subjected to continuous air bubbling. The lower hook was fixed at the bottom of the organ bath and the upper one was connected to an isotonic transducer (Harvard Transducer). The ileum contractions were recorded, under $1 \mathrm{~g}$ resting tension, following $60 \mathrm{~min}$ for equilibrium period. During this period, the organ bath solution was refreshed every $15 \mathrm{~min}$. Isotonic contraction, elicited by $\mathrm{Kcl}$ were recorded using a Harward isotonic transducer and displayed on a (Harward universal Oscillograph UK) pen recorded device. A contraction -response curve was also obtained by cumulative addition of $60 \mathrm{mM} \mathrm{Kcl}$. Each extract concentration had 5 min of contact with the tissue before effects were evaluated.

\subsection{Procedure}

\subsubsection{Effect of Extract on $\mathrm{KCl}$-induced Ileum Contraction}

Rat ilea suspended in tyrode's solution showed irregular spontaneous contraction activity, which was attenuated by changing the bath fluid. $60 \mathrm{mM}$ KCL non-receptor stimulation for opening ca2+ channel produced a sustained tonic contraction, which was maintained during the course of the experiment. After administering of $60 \mathrm{mM}$ KCL to the bath solution, various concentration of extract $(0.1,0.2,0.3,0.4,0.5,0.6,0.7,0.8 \mathrm{mg} / \mathrm{ml})$ was added sequentially to the bath.

\subsubsection{Effects of Histamine (agonist)}

In the other stage of the experiment, to investigate the role of histamine in the presence of parsley seeds extract, after recording the contractionary effect resulted from histamine on the isolated tissue then without washing, parsley seeds extract $(0.2 \mathrm{mg} / \mathrm{ml})$ were added to the organ bath.

\subsubsection{Effect of an H2-Receptor Antagonist}

In separate experiments to investigate the possible mechanisms of the relaxation response induced by parsley seeds extract, the strip of ileum was equilibrated and contracted with $60 \mathrm{mM} \mathrm{KCl}$, then after $30 \mathrm{~min}$ tissue incubations with Cimetidine $(0.004 \mathrm{mg} / \mathrm{ml})$ parsley seeds extract $(0.2 \mathrm{mg} / \mathrm{ml})$ were added to the bath.

\subsection{Measurements and Statistical Analysis}

The obtained data were analyzed by using Statistical Package for the Social Sciences software (SPSS Inc., Chicago). Changes in contractile force induced by extracts and antagonists were calculated in the form of the mean \pm standard error of the mean. The statistical test of ANOVA and least significant difference post-hoc tests were used to compare the different concentrations of the extract and Student $t$-test was employed to compare the two groups with each other. $P<0.05$ was considered to be a significant difference. 
The Role of Histaminergic H2 Receptors on Spasmolytic Activity of Hydroalcoholic Extract of Parsley (Petroselinum crispum) Seeds in Isolated Rat's lleum

\section{Results}

\subsection{Effect of Extract on KCl-Induced Contraction}

Cumulative addition of extract $(0.1,0.2,0.3,0.4$, $0.5,0.6,0.7,0.8 \mathrm{mg} / \mathrm{ml}$ ) significantly reduced ileum contraction induce by $60 \mathrm{mM} \mathrm{Kcl}\left({ }^{* * *} \mathrm{P}<0.001, \mathrm{n}=\right.$ 7) in a dose-dependent manner (Figure 1).

\subsection{Spasmolytic Effect of Extract in the Presence of Histamine}

To investigate the role of histamine relaxant activity parsley seed extract after recording the effects of histamine contraction $(0.1 \mathrm{mg} / \mathrm{ml})$ without washing, concentration $(0.2 \mathrm{mg} / \mathrm{ml})$ of parsley seed extract was added to organ bath. The results showed that extracts at present histamine did not

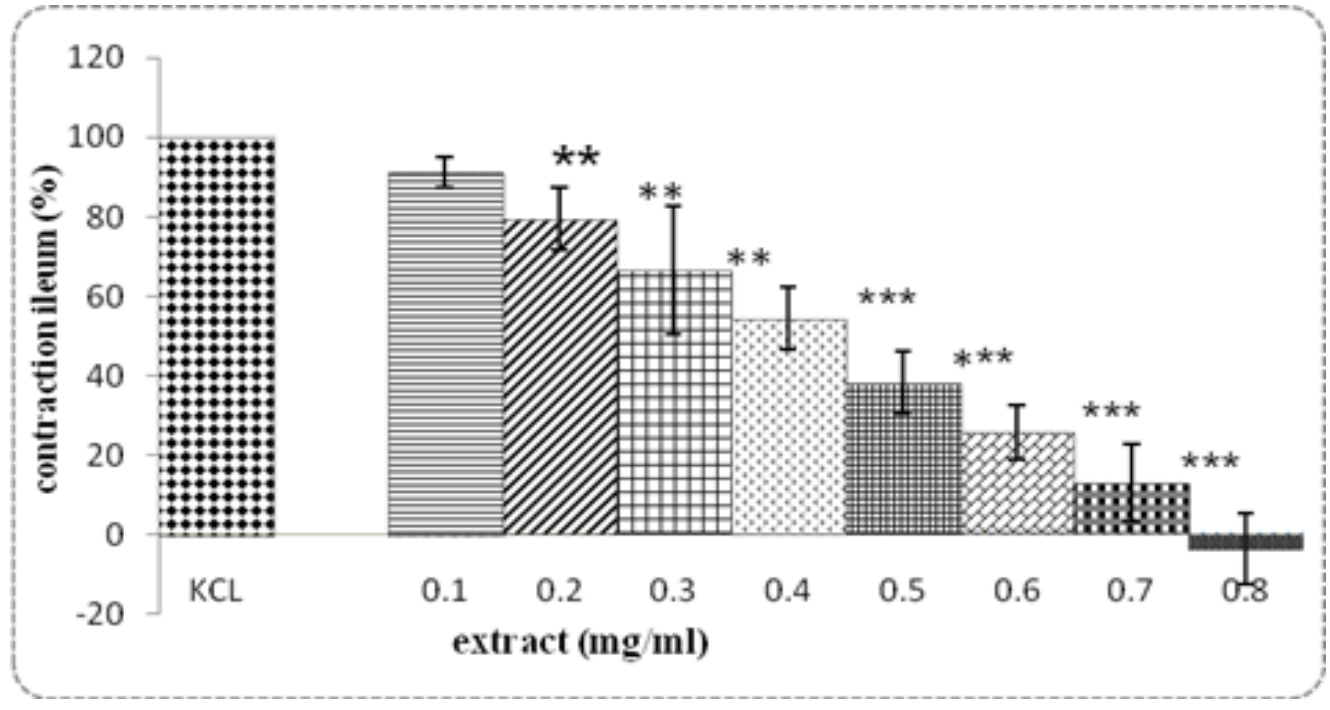

Fig. 1. Spasmolytic effect of cumulative concentrations of parsley extract on $\mathrm{KCl}$-induced $\mathrm{P}<0.01, \mathrm{P}<0.001$

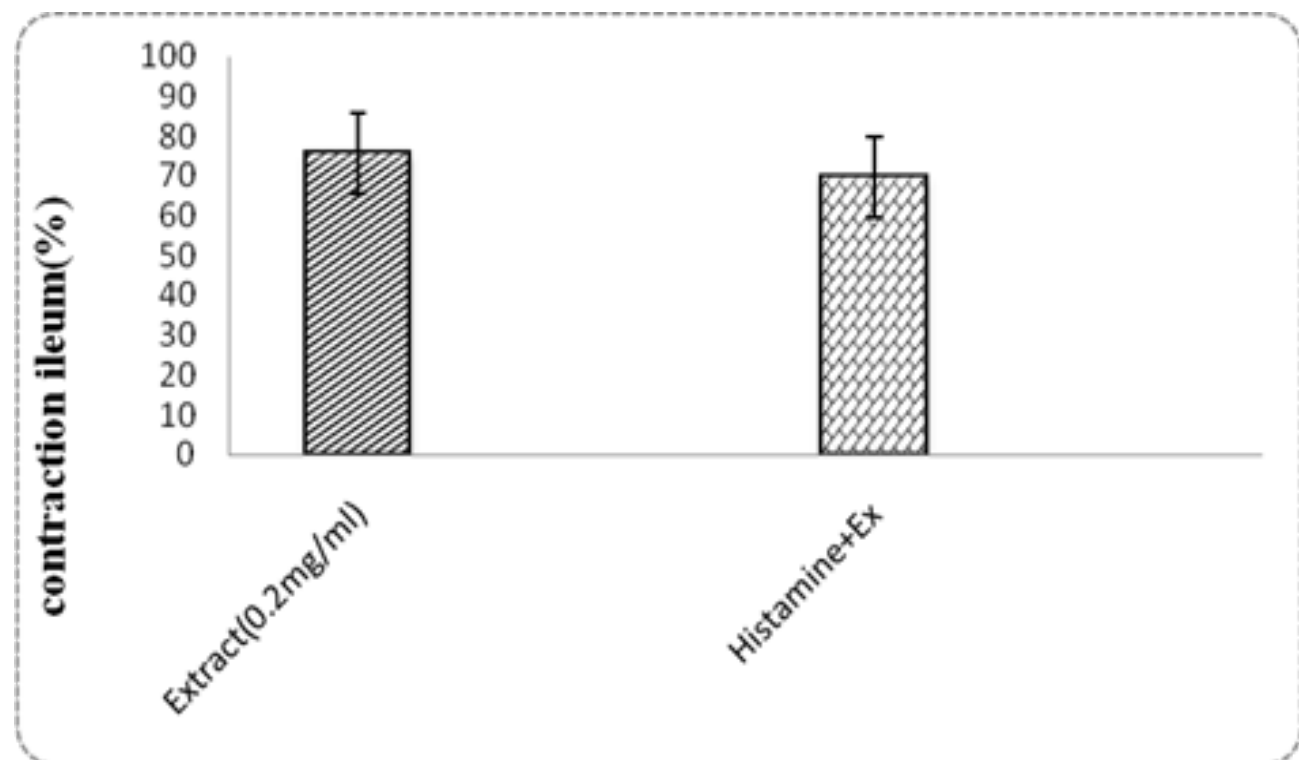

Fig. 2. Effect of Histamine on the relaxant activity of parsley on ileum contractions induced by $\mathrm{KCl}(60 \mathrm{mM})(\mathrm{n}=7)$. 
have a significant effect on tissue contraction $(n=7)$ (Figure 2).

\subsection{Spasmolytic Effect of Extract in the Presence of Cimetidine}

Incubation of ileum preparation (30 $\mathrm{min})$ with Cimetidine $(0.004 \mathrm{mg} / \mathrm{ml}, \mathrm{n}=7$ ) as a histaminergic $\mathrm{H} 2$ receptors antagonist, then without washing tissue stimulation by $\mathrm{Kcl}(60 \mathrm{mM})$ and then parsley seeds extract $(0.2 \mathrm{mg} / \mathrm{ml})$ was added to the organ bath. The result showed that Cimetidine did not alter the Extract $(0.2 \mathrm{mg} / \mathrm{ml})$ spasmolytic effect on ileal contractions induced by $\mathrm{KCl}(60 \mathrm{mM})$ (Figure 3).

\section{Discussion}

The purpose of this work is to study the influence of parsley seed extract on contraction activity of rat is ileum induced by spasmogen and compare the effect of $\mathrm{H} 2$ receptor antagonist and histamine (general agonist). Ultimately, the goal is to investigate the benefits of this drug for gastrointestinal disorders.

Diarrhea has resulted from an imbalance between the absorptive and secretory mechanisms in the intestinal tract, accompanied by intestinal hurry, and an excess loss of fluid in the feces. In some diarrhoea, the secretory component is predominated, and other diarrhea is characterized by hypermotility ${ }^{2}$. Different plant extracts usually mediate their spasmolytic action through blockage of $\mathrm{Ca} 2+$ influx. This indicates that the plant extract is preventing the increase of calcium ions and muscle tension ${ }^{3}$. This result is in agreement with the results of others which examined the effects of other plants on isolated smooth muscle contraction.

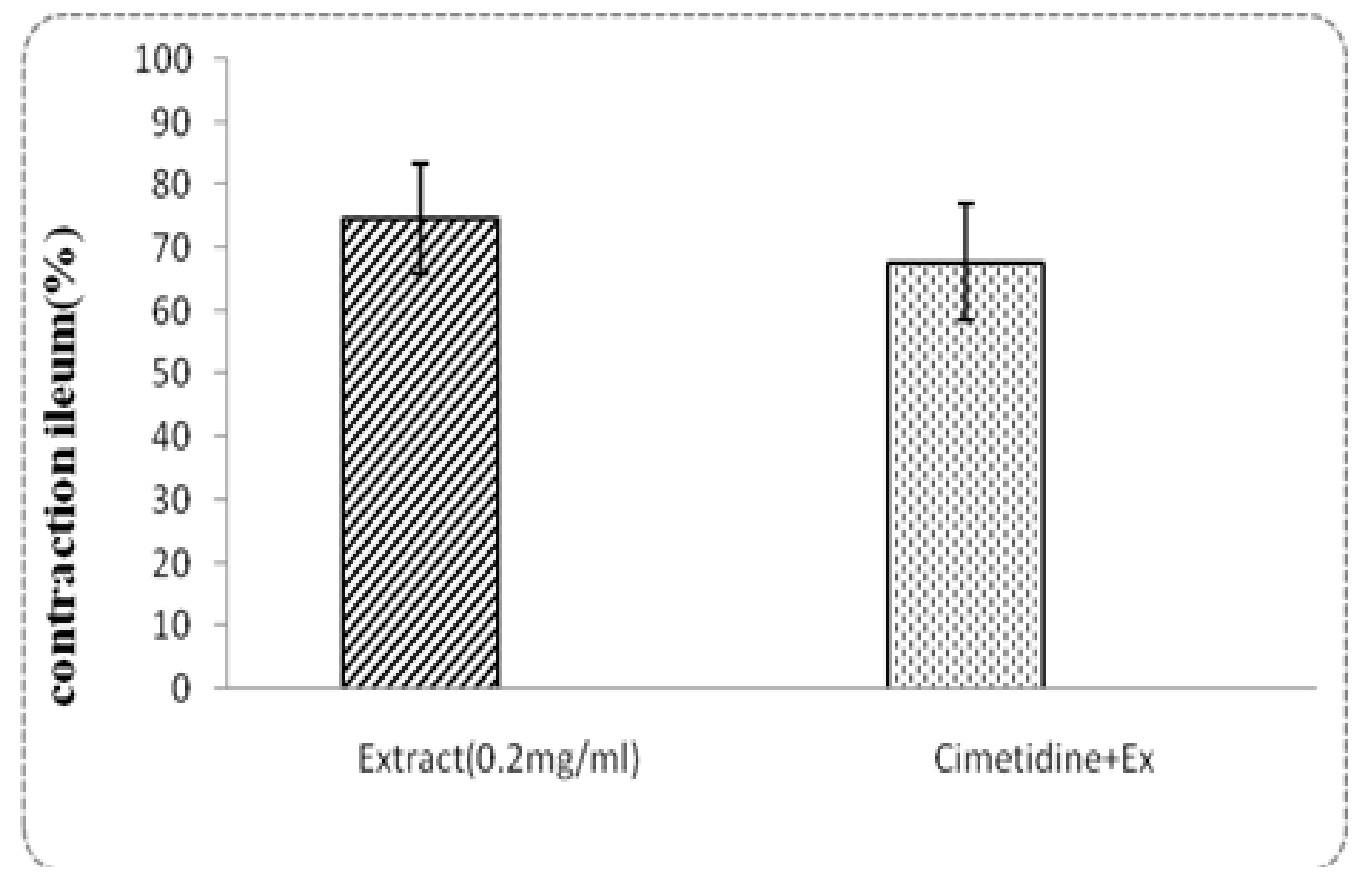

Fig. 3. Effect of Cimetidine on the relaxant activity of parsley extract on ileum contractions induced by $\mathrm{KCl}(60 \mathrm{mM})(\mathrm{n}=7, \mathrm{P}>0.05)$. 
The essential oil in current analysis characterized by the domination of substances: Myristicin apiol, a-pinene, b-pinene ${ }^{8}$. Flavonoids secondary plant metabolites occurring widely in vegetables have been shown to display a remarkable array of biochemical and pharmacology actions, including relaxing effect on intestinal smooth muscles ${ }^{19}$. There have been a number of reports that plants containing essential $\mathrm{oil}^{8}$ and containing flavonoids ${ }^{4}$ possess inhibitory effects on smooth muscles activity. There have been several reports that the antispasmodic effect of the extract is associated with the presence of Flavonoids and essential oil of the plants. Some of them inhibit intestinal motility in vitro. Quercetin, exhibited antispasmodic effect, on guinea-pig isolated ileum. Apigenin ${ }^{5}$ and luteolin inhibited the contractions of the isolated intestine. Also essential oil, such as a-pinene, b-pinene exhibited relaxation effect on isolated rat ileum contractions ${ }^{19}$. These materials have been reported to exhibit calcium antagonist and anticholinergic activities ${ }^{3}$. Several studies in vitro and in vivo showed that those compounds can regulate disturbances of the gastrointestinal tract. Their effects depend on the mechanism involved and the tissue. The spasmolytic effect may due to blockade of the calcium channel. And these flavonoids ${ }^{4}$ and essential oil have been reportedly present in the extract of Parsley ${ }^{5}$, therefore, the extract of Parsley activity possibly was due to this substances.

Other studies reported that ethanol extract of Calotropis procera leaves produced an excellent spasmolytic effect on gastrointestinal smooth muscles (guinea pig ileum) probably due to flavonoids of the crude extract ${ }^{23}$.
In another set of experiments, the extract's mechanism of actions and the role of histamine (general) agonist and Cimetidine (antagonist $\mathrm{H} 2$ receptor) on relaxation was investigated. To evaluate whether the extract has relaxed intestine by binding to agonist and antagonist $\mathrm{H} 2$ histaminergic receptors, the relaxing effect of the extract was examined in the presence of Histamine and Cimetidine. The ineffectiveness of both the spasmolytic effect of extract indicates that agonist (general) and antagonist $\mathrm{H} 2$ histaminergic receptors are not involved in this action. The relaxation of smooth muscles was induced by different mechanisms that include the blocking action on excitatory/inhibitory pathways such as cholinergic ${ }^{24}$, histaminergic ${ }^{25}$, adrenergic $^{19}$, purinergic ${ }^{26}$, GABAergic ${ }^{9}$.

One of the possible mechanisms for the spasmolytic activity of the extract could be mediated through the inhibition of histaminic receptors ${ }^{3}$.

In the alimentary tract, it is well-known that cholinergic and histaminergic transmissions are involved in the regulation of intestinal motility. Drugs can influence cholinergic or histaminergic transmission by acting on their receptors or by affecting the release of endogenous acetylcholine or histamine, respectively. These results show that histamine can induce contractions in isolated chicken ileum ${ }^{27}$ and in the guinea pig ileum ${ }^{25}$.

Other studies also reported that histamine produced dose-dependent contractions in rectum and colon of rat $^{28}$. Many scientists in their investigations have been identified $\mathrm{H} 1, \mathrm{H} 2, \mathrm{H} 3$ 
receptors in the gastrotilal tract of guinea pigs $^{29}$ rats $^{28}$ and chickens ${ }^{27}$.

Histamine exerts its actions by binding to four GPCRs that are differentially expressed throughout the body and designated as the $\mathrm{H} 1, \mathrm{H} 2, \mathrm{H} 3$ and $\mathrm{H} 4$ receptors ${ }^{30}$.

Histamine induces production of inositol phosphates in smooth muscles via $G_{a q}$ protein $\operatorname{activation}^{13}$. Histamine was used as an agonist for stimulating ileum smooth muscles. Histamine is known to cause contraction of smooth muscles of the gastrointestinal tract. Application of histamine to intact smooth muscles produced a concentrationdependent membrane depolarization and increased excitability. On the other hand, Histamine as a histaminergic receptor agonist ${ }^{3}$ activates receptoroperated $\mathrm{Ca} 2+$ channel, elevates $[\mathrm{Ca} 2+]$ and induces contraction via $\mathrm{H} 1$ receptors ${ }^{17}$.

Histamine also activates phospholipase $\mathrm{C}$ and enhances inositol triphosphate (IP3) production ${ }^{13}$ followed by the promotion of $\mathrm{Ca} 2+$ release from intracellular $\mathrm{Ca} 2+$ pools (sarcoplasmic reticulum).

Histaminergic control of gastrointestinal contractility and motility is complex and involves all histamine receptor subtypes. H1 receptors, located in smooth muscle cells, contribute to contractility by increasing calcium availability at the sarcoplasmic level ${ }^{30}$. Histamine-induced contraction of guinea pig ileum is mediated by H1receptors. $\mathrm{H} 2 \mathrm{R}$ is coupled both to adenylate cyclase and to phosphoinositide second messenger systems via separate GTP-dependent mechanisms. Receptor binding stimulates activation of c-Fos, c-Jun, Protein Kinase C (PKC) and p70S6kinase ${ }^{16}$.

Histamine provoked contraction and membrane depolarization in the longitudinal smooth muscle cells of the guinea pig ileum. This may have been the result of on increasing ca2+ partition through voltage-gated and receptor-operated ca2+ channels ${ }^{17}$. There is convincing evidence that can be significant for variation in the degree of the partition of extracellular and intracellular ca2+ in smooth muscles contraction. Calmodulin (Cam) plays an important role in contraction behaviour and electrical rhythmicity ${ }^{8}$.

It's evident that histamine stimulates the enteric neurons and $\mathrm{H} 2$ agonists shown the increase, the amplitude of electrically evoked contractions of the longitudinal muscle. Therefore it is possible that histamine activates the longitudinal muscle excitatory motor neurons. Histamine produces a contraction of the circular muscle in the guinea pig small intestine. Histamine, acting via $\mathrm{H} 1$ - and $\mathrm{H} 2$ receptors makes the depolarization of guinea pig myenteric neurons with the increase in the input resistance, augmented excitability and repetitive spike demonstrated. The enzymes involved in the synthesis of histamine and its mRNA is present in enteric neurons. Histamine plays a functional role in intestinal motility ${ }^{29}$. The histamine $\mathrm{H} 2$ receptor is a couple to the adenylate cyclase system in a variety of tissues (e.g., brain, stomach, heart, gastric, mucosa, lung). Moreover, cell lines transfected with the cloned $\mathrm{H} 2$ receptor genes showed an $\mathrm{H} 2$ receptor-mediated increase of cAMP. In addition, alternative signaling pathways for $\mathrm{H} 2$ receptor have 
been identified. An $\mathrm{H} 2$ receptor-mediate increase of the intercellular $\mathrm{ca}_{2+}$ concentration and/or $\mathrm{IP}_{3}$ level was observed.

The distinctive finding in this study is that an alcohol extract of parsley seeds is a relaxant of rat's ileum smooth muscles and that histaminergic $\mathrm{H} 2$ receptors antagonist (Cimetidine) and agonist (Histamine) do not change relaxation induced by the extract. And cimetidine did not significantly affect the activity of the extract, suggesting that extract does not have any effects on histaminergic $\mathrm{H} 2$ receptors. It may be used to treat digestive disorders like cramps and diarrhea. Other experimental approaches will be necessary to delineate the exact relationship between extract of parsley and the histaminergic receptors.

\section{Conflict of Interest Statement}

We declare that we have no conflict of interest

\section{Acknowledgment}

The authors give thanks to the Department of Biology, Shahid Chamran University as the sponsor of this research.

\section{References}

1. Mahmood S, Hussain Sh, Malik F. Critique of medicinal of conspicuousness Parsley (Petroselinum crispum): A culinary herb of Mediterranean region. P J Pharmacol. 2014; 27(1):193-202.
2. Naseri MKG, Moghaddam MA, Bahadur S.Antispasmodic effect of Tecoma stans (L.) Juss leaf extract on rat ileum. DARU. 2007; 15:3.

3. Bigovic D, Brankovic S, Kitic D, Radenkovic M, Jankovic T, Savikin K, Zivanovic S. Relaxant effect of the ethanol extract of Helichrysum plicatum Asteraceae on isolated Rat Ileum contractions. J of Molec. 2010; 15:3391-401. Crossref. PMid:20657488

4. Mamadou G, Meddah B, Limas-Nzouzi N, El Haj AA, Bipolo S, Mokondjimobé E, Mahraoui L, Faouzi MA, Ducroc R, Cherrah Y, Eto B. Antispasmodic phytomedicine from traditional, utilization to rational formulation: The functional approach. Phytopharmacol. 2011; 1(3):20-3.

5. Moradi MT, Rafieian-Koupaei M, Imani-Rastabi R, Nasiri J, Shahrani M, Rabiei Z, Alibabaei Z. Antispasmodic effects of yarrow (Achillea millefolium l.) extract in the isolated ileum of the rat. J of Pharmacol. 2013; 10(6):499-503. Crossref.

6. ELai-Har Tang E, Rajarajeswaran, Fung Sh Y, Kanthimathi MS. Petroselinum crispum has antioxidant properties, protects against DNA damage and inhibits proliferation and migration of cancer cells. J of the Science of Food and Agriculture. 2015; 95:2763-71. Crossref. PMid:25582089 PMCid:PMC5024025

7. Antal I, Edit Pápay Z. Study on the antioxidant activity during the formulation of the biological active ingredient. Euroscientific J. 2014; 3:1857-743.

8. Moazedi AA, Mirzaie DN, Seyyednejad SM, Zadkarami MR, Amirzargar A. Spasmolytic effect of Petroselinum crispum (parsley) on Rat s Ileum at different calcium chlorid concentration. Paki J of Bilogical Sciences. 2007; 10(22):4036-42. Crossref.

9. Hansen MB. Neurohumoral control of gastrointestinal motility. Physio Res. 2003; 52:1-30. PMid:12625803

10. Grasa L, Rebollar E, Arruebo MP, Plaza MA, Murillo $\mathrm{MD}$. The role of $\mathrm{Ca} 2+$ in the contractility of rabbit 
small intestine in vitro. J of Physio and Pharmacol. 2004; 55(3):639-50. PMid:15381833

11. Sedighi M, Kopaei MR, Ahmadabadi MN, Godarzi I, Baradaran A. In vitro impact of hydro alcoholic extract of rosa damascena mill on Rat Ileum contractions and the mechanisms involved. Int $\mathrm{J}$ of Preventive Medi. 2014; 5(6):775-67.

12. Soto SE, Maldonado DG, Espana PC, Grespo FA, Salcedo SJC. Spasmoiytic effect of Mentha pulegium L. Involves ionic flux regulation in rat ileum scripts. Smooth Muscle Research. 2010; 46(2):107-17. Crossref.

13. Desch I, Leurs R. Histamine receptors. Tocris Bios. 2008; 29:2.

14. Smolinski S, Jutel M, Crameri R, Mahony LO. Histamine and gut mucosal immune regulation. Eur J of Allergy and Clinical Immunol. 2014; 69:273-81. Crossref.PMid:24286351

15. Hallgren J, Gurish MF. Granule maturation in mast cells: Histamine in control. Eur J of Immunol. 2014; 44:33-36. Crossref. PMid:24319003

16. Shahid M, Tripathi T, Sobia F, Moin Sh, Siddiqui M, Ali Khan R. Histamine, histamine receptors, and their role in immunomodulation: An updated systematic review. The Open Immunol J. 2009; 2:941. Crossref.

17. Yamanaka K. Kitamura K. Electrophysiological and mechanical characteristics of histamine receptors in smooth muscles cells of the guniea pig ileum. Eur J of Pharmacol. 1987; 144:9-37.

18. Koutsovlti-Papadopoulos M, Kounenis G, Elezoglou V, Kokolis N. Effect of cimetidine on the histamine and dimaprit induced responses on the guinea pig ileum during development. Gen Pharmacol. 1993; 24(4):1021-6.Crossref.

19. Damabi NM, Moazedi AA, Seyyednejad SM. The role of $\alpha$ - and $-\beta$ adrenergic receptors in the spasmolytic effects on rat ileum of Petroselinum crispum
Latifolum (parsley). Asian Pac Jof Tro Medicine. 2010; 866-70.

20. Nasu T, Murase h, Shibata H. Manganese Ions induce tonic contraction after relaxation in a high-K+ medium in the ileal longitudinal smooth muscle of guinea-pig. J Pharm Pharmacol. 1994 Sep; 46(9):7359. Crossref.PMid:7837042

21. Dale MM. An inhibitory effect of acetylcholine on the response of the guinea-pig ileum to histamine. British J of Pharmacol. 1958; 13(1):17. Crossref.

22. Vyas S, Verma SCb. The direct excitatory effects of cimetidine on the smooth muscle of guinea pig ileum. Agents and Actions. 1981; 11:3. Crossref.

23. Jagadeesh K, Revankar Sh, Jagadeesh SC. Spasmolytic effect of ethanolic extract of calotropis procera leaves on in-vitro guinea pig ileum. Asian Pac J Health Sci. 2014; 1(2):65-8.

24. Bolton TB. Mechanisms of action of transmitters and other substances on smooth muscle. Am Physio Society. 1979; 59(3):607-718. Crossref.

25. Morel N, Paul Hardy J, Godfraind T. Histamineoperated calcium channels in the intestinal smooth muscle of the guinea-pig. Eur J of Pharmacol. 1987; 13(5):69-75. Crossref.

26. Van Crombruggen K, Van Nassauw L, Timmermans JP, Lefebvre RA. Inhibitory purinergic P2 receptor characterization in rat distal colon. Neuropharmacol J. 2007; 53:57-71. Crossref. PMid:17612577

27. Daude RB, Mishra SV, Chega de RY, Amrutkar SV. Bioassay of histamine by using isolated chicken ileum. World J of Pharmacy and Pharmaceutical Science. 2016; 5(1):1221-25.

28. Singh SH, Mandal MB. In vitro study of acetylcholine and histamine-induced contractions in colon and rectum of adult and neonate rats. Indian J of Physiolo Pharmacol. 2013; 57(2).

29. Mascolo N, Izzo AA, Costa M, Capasso F. The role of histamine $\mathrm{H} 1, \mathrm{H} 2$ and $\mathrm{H} 3$ receptors on enteric 
The Role of Histaminergic H2 Receptors on Spasmolytic Activity of Hydroalcoholic Extract of Parsley (Petroselinum crispum) Seeds in Isolated Rat's Ileum

ascending synaptic transmission in the guinea pig

Ileum. The Am Society for Pharmacol and Experi

Therapeutics. 1998; 287:952-7.
30. Deiteren A, De Man JG, Pelckmans PA, De Winter BY. Histamine $\mathrm{H} 4$ receptors in the gastrointestinal tract. British J of Pharmacol. 2015; 172:1165-78. Crossref.PMid:25363289 PMCid:PMC4337694 